\title{
Developing Critical Thinking of Students with Hearing Impairment for Computational Thinking in Mathematics with E Module Design
}

\author{
Wahyu Andriyani ${ }^{1}$, Suparman ${ }^{2 *}$, Rosman Ilato ${ }^{3}$, Arwan Mhd Said ${ }^{4}$, Zuchri Abdussamad ${ }^{5}$, Astuti \\ Salim $^{6}$, Sunardin ${ }^{7}$, Muchtar Ahmad ${ }^{8}$, Musrowati Lasindrang ${ }^{9}$, Handaru Catu Bagus ${ }^{10}$, Rosita \\ Wondal $^{11}$ \\ ${ }^{1,2}$ Postgraduate Program in Mathematics Education, Faculty of Teacher Training and Education, Universitas Ahmad Dahlan, \\ Yogyakarta, Indonesia \\ ${ }^{3,5,8}$ Faculty of Economics, State University of Gorontalo, Gorontalo, Indonesia \\ ${ }^{4}$ Faculty of Tarbiyah and Teacher Training, Institut Agama Islam Negeri Ternate, Ternate, Indonesia \\ ${ }^{6,11}$ Faculty of Teacher Training and Education, Universitas Khairun, Ternate, Indonesia \\ ${ }^{7}$ Faculty of Teacher Training and Education, Universitas Cokroaminoto Palopo, Palopo, Indonesia \\ ${ }^{9}$ Faculty of Agriculture, State University of Gorontalo, Gorontalo, Indonesia \\ ${ }^{10}$ Faculty of Postgraduate Program, Universitas Negeri Jakarta, Jakarta, Indonesia \\ *suparman@pmat.uad.ac.id
}

\begin{abstract}
This research aims to analyse and design the e-module learning based on computational thinking for increasing the critical thinking skill of students with hearing impairment. This research used the qualitative descriptive approach. The subjects of the research are the students of the VII grade of Special Junior High School of Djojonegoro Temanggung. The data collection instruments used in this research were the guidelines for the validation of the e-module design, the guidelines for observing the implementation of learning in class, and the interview guidelines for the teacher. Data is analyzed by reducing, serving, and concluding. The result of the research is analyzing the necessity of the e-module and designing the e-model based on analysis needs. The e-module designed based on computational thinking to increase the critical thinking skill of the students with hearing impairment appropriated by their character, curriculum, and student's tasks. The results of this study can be used as a guide for mathematics teachers in developing e-module that make students understand mathematics and have critical thinking skills simultaneously. The advantage of this research is to integrate critical thinking skills into e-module.
\end{abstract}

Keywords

Computational Thinking; Critical Thinking; Students with hearing impairment; E-Module.

Article Received: 18 October 2020, Revised: 3 November 2020, Accepted: 24 December 2020

\section{Introduction}

Education is an important thing for the young generation to get both science and skill. The science and skill are learned by the students in the class through the affective and fascinating learning by the teachers (Yuanita et al., 2018). Critical thinking skills are one of the most important to be developed (Han \& Appelbaum, 2018). These skills could be developed by creating a method where the students not only received the concept but also be active participants (Rasiman, 2015; Kusaeri \& Aditomo, 2019). Critical thinking is the ability to think logically and systematically in valuing, solving problems, and researching (Runisah et al., 2017).
Critical thinking is the ability to solve problems (Rasiman, 2015). This skill is important in mathematics for it could be developed the quality of mathematics to be better and meaningful learning (Firdaus et al., 2015; Cahyani \& Putri, 2019).

Mathematics is an important ability that should be had by the students (Arnidha \& Hidayatulloh, 2019). It is a universal science-based on the development of modern technology. In mathematics, the students should be given realistic skills, analytical, critical, and creative thinking (Wahyudi, 2016; Anwar, 2018). With the development of science and technology, the innovation in the pedagogy in basic, mediate to 
tertiary and the children with special needs also should be developed (Arnidha \& Hidayatulloh, 2019).

According to Keil in (Arnidha \& Hidayatulloh, 2019), special education aims to focus on creating the standard curriculum for children with special needs. The deaf children are they who had a deficiency in their hearing sensory caused by missed of some or all of the instruments of hearing sensory. They were difficult to understand language or communication. In learning, students with hearing impairment hard to developed themselves which affected their ability to receive when the teacher delivered the lesson. The intelligence of the students with hearing impairment is potentially as same as the ordinary students but their development functionally is influenced by their ability of language (communication), limited information, and the abstraction of language.

The upgrading of achievement the students with limited hearing sensory relates to the approach of the lesson in challenging problems of mathematic. The lesson focuses on the skill to think advanced and problem solving (Shelton \& Parlin, 2016). In (Sondakh, 2018), Polya writes about the method of solving the mathematics problem. This approach is called computational thinking (Sondakh, 2018). Computational Thinking (CT) is the process of thinking involved in problem formulation and problem solving (Khasyyatillah \& Osman, 2019). CT changes the problem to be the computational solution, it is an algorithm which avowed as the critical skills, especially for mediate school (Sondakh, 2018).

Lesson material is one of many ways to develop the skill of the students. It is part of many sources in the learning activity. It contains the information both of printing or electronic that is used by the students for learning (Cahyadi, 2019). In addition, learning by using modules helps students in identifying and interpreting the information. In the module, the mathematics content not only explains the steps or using formulation in solving the problem but also to giving an understanding of the concept of integration and critical thinking skill (Firdaus et al., 2015).

From the interview and the observation, the researchers get the data about the mathematics lesson in Special Junior High School of Djojonegoro Temanggung. Generally, the teachers had been used instruments of learning, they are books and student's tasks but have not developed the critical thinking skill of the students yet. According to Kluwin dan Moores (Govindan \& Ramaa, 2014), difficulties in mathematics are due to the lack of emphasis on mathematics education for students with hearing impairment and reduced opportunities for incidental learning. Another factor according to Pagliaro (Kelly \& Pagillaro, 2014) the teacher who teaches students with hearing impairment is not quite enough to preparing the mathematic materials and limited in knowledge or using the language.

Based on the explanation above, the researchers analyzing, designing, and developing the emodule design that is combined with Computational Thinking learning to developing the critical thinking skill of students with hearing impairment.

\section{Methodology}

This research is categorized into kind of qualitative descriptive. This research did in the special junior high school of Djojonegoro, Temanggung. The subjects core VII-grade students of special junior high school of Djojonegoro, Temanggung. The instrument for collecting the data is the validation of the guidelines of the mathematics module. The instruments to validating appropriated to the curriculum. The questionnaire is filled by rating and qualitative suggestions from the experts. This suggestion is used to revising the product (Suhendri \& Suparman, 2019). The level of validation of learning products is indicated by the score given by the validators through the emodule design validation sheet. The validators 
include media experts and material experts. The

shown

in

Table

1. scores provided for validating the product are

Table 1. Validating the Product

\begin{tabular}{cc}
\hline Criteria & Score \\
\hline Excellent & 5 \\
Very Good & 4 \\
Good & 3 \\
Fair & 2 \\
Poor & 1 \\
\hline
\end{tabular}

Data is analyzed by reducing, serving, and concluding.

\section{Results and Discussions}

Based on the observation of the curriculum, the researchers find that the school has used the curriculum that appropriates the fundamental competence, basic competence, and the indicators in the curriculum of 2013 (K-13). Every lesson that has been taught is proper to the indicator of accomplishment of competence. The implementation of learning, a teacher gives materials or lesson which is under the grade. For example, the teacher gives the IV-grade materials to students of Junior High School.

Based on the observation, the researchers found that students with hearing impairment are actively asking the teacher when they were given tasks by the teacher. The teacher gives good to respond to the passive students when teaching. Based on the interview with Ibu Dwi Febri Wahyu as the teacher of VII- grade of Special Junior High School (SLBN) of Djojonegoro, Temanggung, the

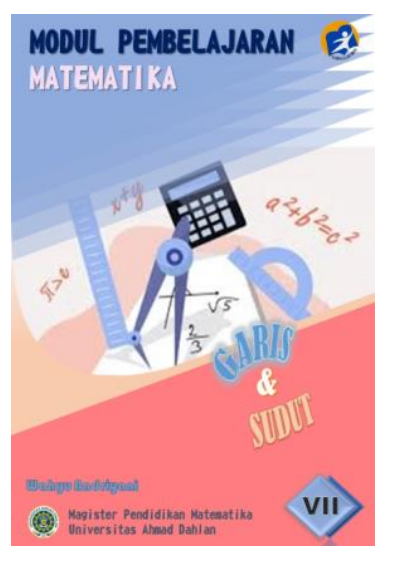

researcher found that the students with hearing impairment were difficult to understand the mathematic lesson but they actively asked when they faced a difficult problem. In addition, she said that the obstacles in learning mathematics are giving understanding to the students about the materials and limited media.

In this section, the researcher is designing the emodul base on computational thinking to develop the critical thinking skill of the VII- grade students of Special Junior High School (SMPLB) The cover of this e-module consists of a Logo of $\mathrm{UAD}$, the Title of the module, title of the lesson, target of the user, the author, and the institution. The cover is important for it shows the contents. The cover is shown in figure 1 . 
Figure 1. Mathematics Module based on the Computational Thinking Learning The conceptual mapping of this e-module contains learning in the class. The conceptual mapping is the topics which had to learn. The conceptual shown in figure mapping helps the teacher to improve effective

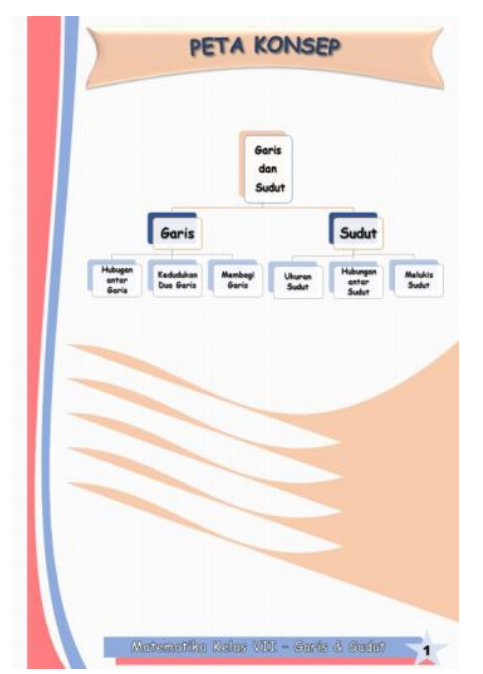

Figure 2. Conceptual Mapping

The main lesson of this e-module contains basic competence and indicators of the accomplishment of competence. The main lesson is shown in figure

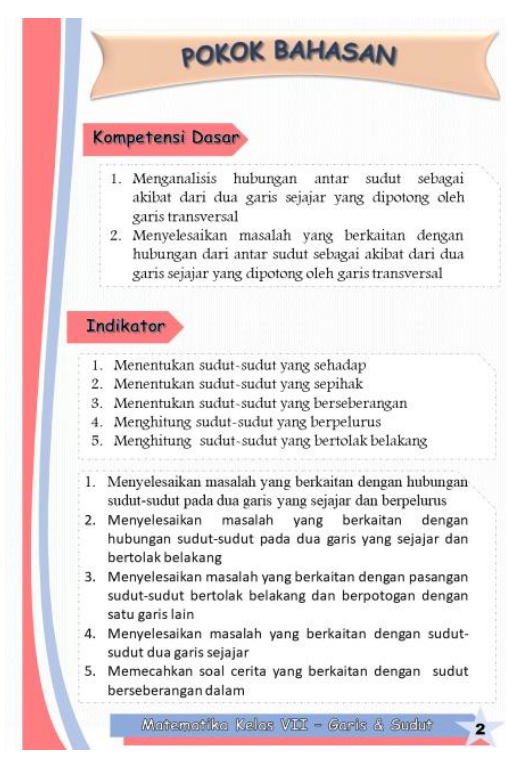

Figure 3. Main Lesson

This page contains the summarizing of the line and angle. The summary of the lesson hopefully could help the students to imagine the lesson that will be taught. The page of the lesson is shown in figure 4. 


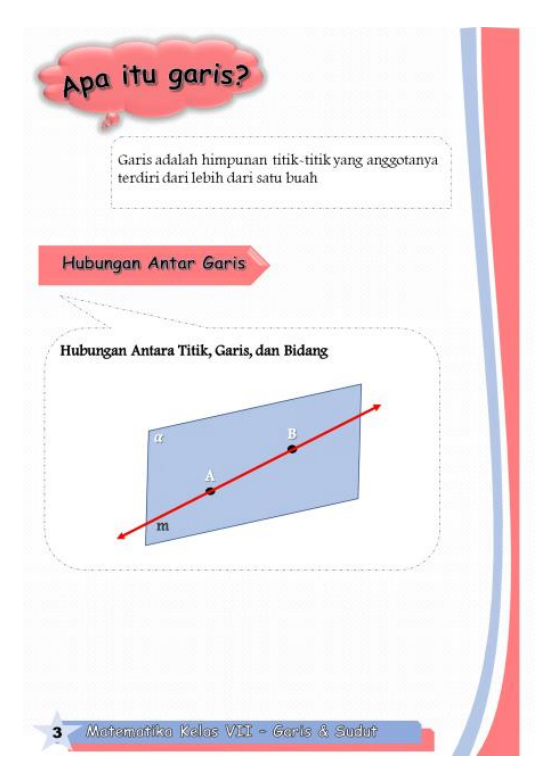

Figure 4. Summarizing the Lesson

The Exercises in this computational thinking emodule contains some problems that should be solved by the students. This exercise aims to trigger critical thinking skills in mathematics about the line and angle. An example of the exercise is shown in figure 5 .

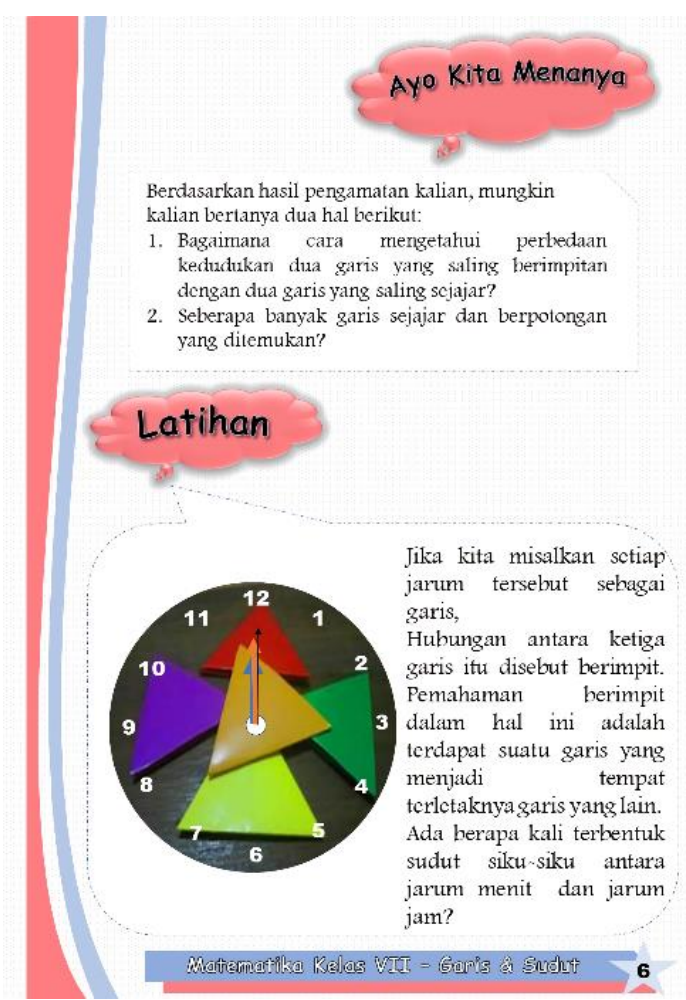

Figure 5. Exercises

The quiz page in this e-module contains the exercises that developing and sharpening the critical thinking skill of the students and increasing the insight about the line and angle. The page of the quiz is shown in figure 6 . 


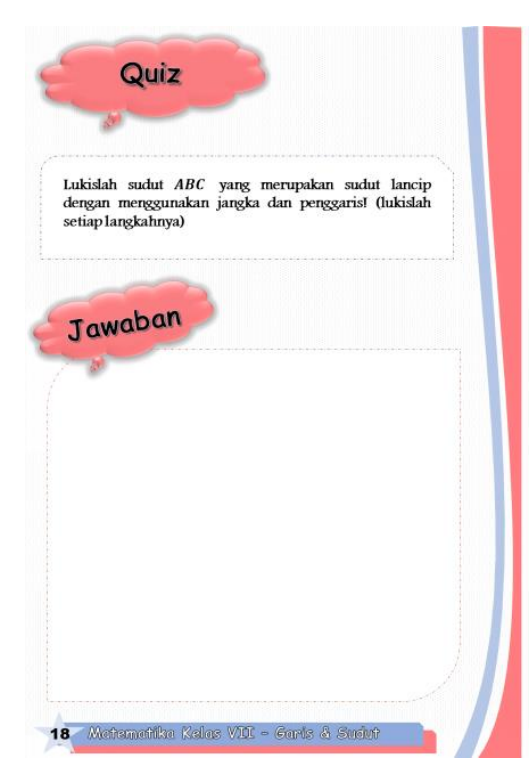

Figure 6. Page of Quiz

The e-module is designed appropriately for the level of computation thinking by Malik (Malik \& Wara, 2018). The levels are 1) Formulating The Problem, 2) Logically ordering and analyzing the data, 3) Presenting the data uses abstraction, 4) Optimizing the solution uses an algorithm (some steps). 5) Identifying, analyzing, and implementing an effective possible solution. 6) Generalizing and transferring problem solving. Computation thinking techniques in (GarePenalvo, 2016; Wing, 2017) are 1) Simplification 2) introduction of the system 3) Generalization 4) Designing the algorithm.
The e-module design was examined by validating the materials and media. In validation of the materials, assessment is used for determining the validity of the e-module design. E-module The emodule that had been approved by the assessor then validated by the validator, lecturer, expert of media. The validation of the e-module uses instruments of assessment. It formed in questions and questionnaires. After that, if the instrument is valid, the instrument can be used by the experts of materials and media to assessing products to be developed. Some suggestions from the experts are summarizing in table 2.

Table 2. The Suggestions from the Expert

\begin{tabular}{ll}
\hline \multicolumn{1}{c}{ Suggestions and Comments } & \multicolumn{1}{c}{ Following } \\
\hline The conceptual map in less detail & The conceptual map has been fixed with more details \\
Adding the logogram of K-13 & Has been added the logogram of K-13 \\
Adding the lesson & Has been added \\
\hline
\end{tabular}

The suggestions from the expert are the references for the researcher to revise the product. In addition, the properness of the lesson is judged by two experts. The result of the score from the questionnaire about the properness of the instructional design media by the expert is shown in table 3

Table 3. The Result of the Questionnaire of the Properness Lesson

\begin{tabular}{ccc}
\hline Assessor & Position & $\begin{array}{c}\text { Criteria for the } \\
\text { Qualitative Data }\end{array}$ \\
\hline Anang Arga P. & Math. Teacher & Excellent \\
\hline
\end{tabular}




\begin{tabular}{lll}
\hline Veni Anggreani & Math. Teacher & Excellent \\
\hline
\end{tabular}

Based on table 3, the researcher concluded that the e-module design is categorized to be an excellent e-module design. As in (Isnaepi \& Suparman, 2019; Suprotun \& Suparman, 2019), the next research would be extended on the development, implementation and evaluation. In this phase, the product was developed to fulfill the criteria of practice and effective when used.

\section{Conclusion}

This research designed mathematics e-module based on the computational thinking method. In the analyzing, the researcher explaining the curriculum, learning instrument, and analyzing the characteristic of the students with hearing impairment. From the observation, the school has used the curriculum of 2013 or called K-13. The researchers find that the students with hearing impairment were given the materials under the grade of them for they cannot understand immediately. The characteristic of the students with hearing impairment, they were actively asked when the teacher give them tasks. On the other side, if the students are not active, the teacher will help to guide them with a good response. In the designing, the researchers designed the cover, the conceptual mapping, the materials lesson, exercise, and quiz. The activity of students that triggering the critical thinking skill of the students finds in the exercise part.

\section{Limitations and Future Studies}

In this research, the researchers described on the analysis and design of the e-module for the students with hearing impairment. The future research can be extended on the development, implementation and evaluation.

\section{Acknowledgement}

The researchers would like to express their gratitude to the Postgraduate Program in
Mathematics Education (Universitas Ahmad Dahlan), Universitas Negeri Gorontalo, Institut Agama Islam Negeri Ternate, Universitas Khairun, Universitas Cokroaminoto Palopo, and Universitas Negeri Jakarta which has given guidance and the facility to finish this research. The researchers also thanked all of the people who helped and given encouragement in this research.

\section{References}

[1] Yuanita, P., Zulnaidi, H., and Zakaria, E., (2018). The Effectiveness of Realistic Mathematics Education Approach: The Role of Mathematical Representation as Mediator between Mathematical Belief and Problem Solving, Plos One, 13(9), 120.

[2] Han, X., and Appelbaum, R.P, (2018). China's Science, Technology, Engineering, and Mathematics (STEM) Research Environment: a Snapshot, Plos One, 13(4), 1-22.

[3] Rasiman, (2015). Leveling of Critical Thinking Abilities of Student of Mathematics Education Mathematical Problem Solving, Journal on Mathematics Education, 6(1), 40-52.

[4] Kusaeri, and Aditomo, A., (2019). Pedagogical Beliefs about Critical Thinking among Indonesian Mathematics Pre-service Teachers, International Journal of Instruction, 12(1), pp. 573-590.

[5] Runisah, Herman, T., and Dahlan, J.A. (2017). The Enhancement of Students' Critical Thinking Skills in Mathematics through The 5E Learning Cycle with Metacognitive Technique, Advances in Social Science, Education and Humanities Research, 57, 101-106.

[6] Firdaus, Kailani, I., Nor Bin Bakar, Md., and Bakry, (2015). Developing Critical Thinking Skills of Students in 
Mathematics Learning, Journal of Education and Learning, 9(3), 226-236.

[7] Cahyani, A., and Putri, S.O, (2019). Inovasi Pendidikan Melalui Kemampuan Berpikir Kritis, [Educational Innovation Through Critical Thinking Ability], Prosiding Seminar Nasional Pendidikan FKIP, 2(1), 286-297.

[8] Arnidha, Y., and Hidayatulloh, (2019). Mathematical Representation of Deaf Students in Problem Solving Seen from Students' Creative Thinking Levels, Journal of Physics: Conference Series, 1155(012030), 1-9.

[9] Wahyudi, (2016). The Development of Realistic Mathematics Education (RME) Model for the Improvement of Mathematics Learnings of Primary Teacher Education Program (PGSD) Students of Teacher Training and Education Faculty (FKIP) of Sebelas Maret University in Kebumen, Proceeding ICTTE, 2(1), 369-381.

[10] Anwar, N.T., (2018). Peran Kemampuan Literasi Matematis pada Pembelajaran Matematika Abad-21," [The Role of Mathematical Literacy Ability in 21st Century Mathematics Learning], Journal PRISMA, vol. 1, 364-370.

[11] Shelton, B.E., and Parlin, M.A., (2016). Teaching Math to Deaf/Hard-of-Hearing (DHH) Children Using Mobile Games: Outcomes with Student and Teacher Perspectives, International Journal of Mobile and Blended Learning, 8(1), 1-17.

[12] Sondakh, D.E., (2018). Reflecting on Computational Thinking Studies for High School Education, Cogito Smart Journal, 4(2), 243-256.

[13] Khasyyatillah, I. and Osman, K., (2019). The Development of CT-S Learning Module on The Linear Motion Topic to Promote Computational Thinking
Thinking, Journal of Educational Sciences, 3(3), 270-280.

[14] Cahyadi, R.A.H., (2019). Pengembangan Bahan Ajar Berbasis ADDIE Model, [Development of ADDIE Model Based Teaching Materials], Education Journal, 3(1), 35-43.

[15] Govindan, N.P., and Ramaa S., (2014). Mathematical Difficulties Faced by Deaf/Hard of Hearing Childern," Conflux Journal Education, 2(7), 28-38.

[16] Kelly, R.R., and Pagillaro, C.M., (2014). Mathematics Word Problem Solving for Deaf Students: A Survey of Practice in Grade 6-12, Journal of Deaf Studies and Deaf Education, 8(2), 104-119.

[17] Suhendri, and Suparman, (2019). Development Mathematics Modules Based on Guided Discovery Learning to Improve Creativity Skills of Blind Students, International Journal of Scientific \& Technology Research, 8(10), 1169-1173.

[18] Malik, S., and Wara, H., (2018). Peningkatam Kemampuan Berpikir Komputasi Siswa Melalui Multimedia Interaktif Berbasis Model Quantum Teaching and Learning [Improving Students' Computational Thinking Ability through Interactive Multimedia Based on Quantum Teaching and Learning Models]. ResearchGate,

https://www.researchgate.net/publication/3 28997960.

[19] Garc-Penalvo, F.J., (2016). What Computational Thinking Is, Journal of Information Technology Research, 9(3), 58.

[20] Wing, J.M., (2017). Computational thinking's influence on research and education for all, Italian Journal of Educational Technology, 25(2), 7-14.

[21] Isnaepi, and Suparman, (2019). Design of Moodle-Based Mathematics Learning to Improve Spatial Ability for Class XII High 
School Students, International Journal of Scientific \& Technology Research, 8(10), 1174-1177.

[22] Suprotun, S., and Suparman, (2019).

Development Learning Design Lift Material Flap with Character Education to Improve Problem Solving Abilities, International Journal of Scientific \& Technology Research, 8(12), 2806-2810 